\title{
Counterfactual Conceptualizations in L2 French: From Cognitive Principles to Semantic and Lexical Realizations
}

\author{
Isabel Repiso ${ }^{1}$ \\ ${ }^{1}$ Institut de Langues et Littératures Européennes, EA 3437, Université de Haute Alsace, Mulhouse, \\ France
}

\begin{abstract}
This preliminary survey examines how 30 native speakers and 30 Spanish learners of French evoke counterfactual scenarios from a semantic and a lexical perspective. Counterfactual thinking is a universal cognitive process in which reality is confronted with an imagined view of what might have been (Kahneman \& Tversky 1982). The world as we know it is based on a set of enabling conditions that can be mutated, i.e., modified in order to evoke counterfactual worlds. This can be done by modifying various elements in a sentence. For example, speakers might produce counterfactual scenarios by replacing an accusative (1) or by changing some attribute of the subject (2).

(1) I should have had coffee at breakfast rather than tea.

(2) If I were a man, my life would have been quite different.

In each case, a specific language property is changed. Example (1) results from a modification operated on transitivity, and example (2) on affectedness. While counterfactual thinking is universal, its concrete form is only shaped in childhood together with the acquisition of the first language. Is this concrete form preserved or changed in second language acquisition? Earlier research has shown that speakers of different languages have different preferences to do that (Repiso 2013). This survey compares whether non-native speakers of French adopt the same preferences which native speakers have at the level of Verb-Argument Constructions (VACs).
\end{abstract}

Résumé. Conceptualisations contrefactuelles en français L2: des principes cognitifs aux realisations sémantiques et lexicales. Cette étude préliminaire explore la façon dont 30 locuteurs natifs et 30 locuteurs hispanophones du français relate des scénarios contrefactuels dans une perspective sémantique et lexicale. La pensée contrefactuelle est un processus cognitif dans lequel la réalité est confrontée à une vision imaginaire de ce qui aurait pu se passer (Kahnenan \& Tversky 1982). Le monde tel que nous le connaissons repose sur un ensemble de conditions de possibilité qui peuvent être changées, c'est-à-dire modifiées afin d'évoquer des mondes contrefactuels. Par exemple, les locuteurs peuvent produire des scénarios contrefactuels en remplaçant un complément d'objet par un autre (1) ou en changeant un attribut du sujet (2). 
(1) J'aurais dû avoir un café plutôt qu'un thé au petit déjeuner.

(2) Si j'étais un homme, ma vie aurait été assez différente.

A chaque fois, une propriété langagière spécifique est modifiée. L'exemple

(1) témoigne d'une modification du ressort de la transitivité, et l'exemple

(2) de l'ordre de l'affectedness. Alors que la pensée contrefactuelle est universelle, sa forme concrète est façonnée durant l'enfance lors de l'acquisition de la langue première. Cette forme concrète est-elle préservée ou changée dans l'acquisition de la langue seconde? Des recherches antérieures ont montré que des locuteurs de langues différentes ont des préférences différentes pour le faire (Repiso 2013). Cette étude observe de façon contrastive si des locuteurs non natifs du français adoptent les mêmes préférences que les locuteurs natifs au niveau des constructions verbe-argument.

\section{Introduction}

Counterfactual thinking is a universal cognitive process in which reality is compared to an imagined view of what might have been (Kahneman \& Tversky 1982). Studies in psychology have shown that mental simulation is governed by specific rules: (i) people tend to imagine how things could have turned out better (upward counterfactuals) rather than worse (downward counterfactuals) (Summerville \& Roese 2008, Dray \& Uphill 2009), and (ii) the most frequent way to make up upward counterfactuals is by restoring the normal value of a variable rather than introducing unlikely events (Kahneman \& Tversky 1982). Are these principles the same for native and for non-native speakers? This will be examined in a 'mutation task', i.e., native and non-native speakers are confronted with a task in which they have to invent alternative scenarios. If both linguistic and non-linguistic knowledge are solicited during the acquisition process, then the question arises whether L1 speakers and L2 speakers' populations (a) behave the same from a procedural ${ }^{1}$ viewpoint in such a task, and (b) combine language units in a similar way. Our results should contribute to explore the architectural structure of language, and more particularly should elucidate whether and to what extent semantics and lexical levels are permeable to L1 - L2 differences.

For each response, the following variables were described:

- Altered variable: is the modification based on the restoration of the normal value of a variable (uphill change, in Kahneman \& Tversky's terminology) or on unlikely events (downhill change).

- Property: is the counterfactual scenario based on a role reversal in the agent (agentivity), a replacement of the direct objet (transitivity), or a neutralization of a subject's attribute (affectedness).

- Type of verb: dynamic or static.

- Type of assessment: negative or positive.

In Table 1, examples of counterfactual scenarios are given in italics. The segments between brackets refer to the information given in the stimulus, allowing a comparison between what might have been $\left(\mathrm{W}_{1}\right)$ and the world as it is $\left(\mathrm{W}_{0}\right)$.

\footnotetext{
${ }^{1}$ The term 'procedural' is polysemic in L2 related fields. In the present article, we talk on 'procedural knowledge' as the mental operations necessary to produce counterfactual responses or, more in general, actions sequences for solving problems (Rittle-Johnson \& Wagner, 1999). Counterfactual thinking is a universal cognitive process based on the comparison of reality and a vision of what might have been. A critical operation in the production of counterfactual scenarios consists of modifying one condition from a set of individually necessary and jointly sufficient conditions of the factual world (Cheng \& Novick 1991).
} 
Table 1. Information configuration investigated ${ }^{2}$.

\begin{tabular}{|c|c|c|c|c|}
\hline Examples & Assessment & Verb & Property & Variable \\
\hline $\begin{array}{l}\text { Karen could not have been } \\
\text { allergic }{ }^{3} \text { (rather than having a } \\
\text { condition) }\end{array}$ & $\mathrm{N}$ & $\mathrm{S}$ & Affectedness & $\begin{array}{c}\text { Allergy } \\
\text { (Uphill change) }\end{array}$ \\
\hline $\begin{array}{l}\text { Karen could have chosen her own } \\
\text { dish }{ }^{4} \text { (rather than Mr. Carlson } \\
\text { chose for her) }\end{array}$ & A & $\mathrm{D}$ & Agentivity & $\begin{array}{c}\text { Dish } \\
\text { (Uphill change) }\end{array}$ \\
\hline $\begin{array}{l}\text { Mr. Carlson could have chosen the } \\
\text { Scallops }{ }^{5} \text { (rather than the mussels) }\end{array}$ & $\mathrm{A}$ & $\mathrm{D}$ & Transitivity & $\begin{array}{c}\text { Dish } \\
\text { (Uphill change) }\end{array}$ \\
\hline $\begin{array}{l}\text { Firemen should have intervened } \\
\text { faster }^{6} \text { ['Firemen' not mentioned } \\
\text { in the stimulus text] }\end{array}$ & A & $\mathrm{S}$ & - & $\begin{array}{l}\text { Others } \\
\text { (Downhill } \\
\text { change) }\end{array}$ \\
\hline
\end{tabular}

The present article is organized in five sections. In the next one, we present our research questions and hypotheses. Subsequently, we introduce Verb-Argument Constructions (VACs) as syntactic frames carrying specific meanings. In the fourth section, counterfactuality is introduced as a semantic subdomain of irreality. In the fifth section, we discuss the sociolinguistic background of our participants and explain the methods used to obtain counterfactual responses. Our results are presented in the sixth section. Section seventh is devoted to discuss the role of L2 proficiency as an explicative factor of some of our results. Finally, conclusions are summarized in section 8 .

\section{Research questions and hypothesis}

As previous studies exploring counterfactuality (Kahneman \& Tversky 1982, Wells \& Gavanski 1989, Mandel \& Lehman 1996, Harris et al. 1996), our data come from a mutation task in which participants were invited to produce three modifications to prevent the negative outcome of a story. The story was presented to them under an input that they had to read prior to be interviewed. In the input text, several factors were mentioned as taking part in the final outcome of the story. The design of the text may prompt inferential processes in the reader so that the factors appear as enabling causes. Three of these variables are critical to our study: an allergy, a promotion, and a decision concerning one dish rather than another. The questions yielding our analyses are the following:

- Do L2 speakers and French natives base their counterfactual modifications on the same stimulus' variables (Allergy / Promotion / Dish)? Do they have significantly different choices?

- Are transitivity, agency and affectedness solicited similarly by French and L2 speakers?

- What are the conceptualizing patterns linked to each of these language properties? Is affectedness more often operated with state verbs (to be, to have) rather than dynamic verbs?

- Are the lists of verbs prompted by a particular stimulus' variable (Allergy / Promotion / Dish) different for French-speaking natives and L2 learners? If their lexical lists are different, does L2 French production account for aspectual representations linked to L1 Spanish?

\footnotetext{
${ }^{2}$ Legend: $\mathrm{N}=$ Negative; $\mathrm{A}=$ Affirmative; $\mathrm{S}=$ Static; $\mathrm{D}=$ Dynamic.

${ }^{3}$ « Elle aurait pu ne pas être allergique» (control group SBJ6\#3).

${ }^{4}$ «Elle aurait pu choisir son plat toute seule ( control group SBJ1\#3).

${ }^{5}$ «Il aurait pu choisir les Saint-Jacques» (control group SBJ6\#1).

${ }^{6}$ « Il aurait fallu que les pompiers soient plus rapides » (control group SBJ22\#3).
} 
Because counterfactual thinking is a human cognitive process depending on maturation constraints such as the mental representation of causality (Hume 1739, Piaget 1963, Lewis 1973, Mackie 1974), there is no reason to assume that counterfactual thinking itself - rather than the language-specific linguistic form - develops differently in childhood. Thus, our hypotheses are:

a. Modifications of semantic properties such as agency, affectedness and transitivity will be similarly distributed in L2 and L1 populations. This is to say that no differences are expected on the knowledge related to those semantic properties.

b. Differences are expected at the grammatical and lexical level for noun-verb constructions ${ }^{7}$.

If these assumptions turn out to be true, logical operations on semantic roles would prove to be a less permeable area for differences between native and L2 speakers. An explanation might be that semantics is less permeable to language-based differences because anchored on universal cognitive prerequisites ${ }^{8}$ ? Results at the lexical level should elucidate the role of the $\mathrm{L} 1$ in the $\mathrm{L} 2$ acquisition in what concerns language representations and its aspectual features [+punctual], [+permanent]. Are the nouns used in our stimulus prompting the same verb lists or lexical repertoires in L1 and L2? Special attention will be given to the immersion effect in the native-like productions.

\section{Verb-Argument Constructions (VACs)}

Verb-Argument Constructions (VACs) have been defined as syntactic frames carrying fairly specific meanings (Ellis et al. 2016). They are thus representative of natural languages' construction grammar and its acquisition implies frequency-biased abstraction of regularities within its components. Consider the variation of sentences carrying the English formulaic put it. Related forms may include satellite morphemes as in, on, onto (put it in / put in on / put it onto). These constructions are exemplifications of the schematic caused-motion Verb-Object-Locative VACs describing a routine function of moving something to a new place or in a new direction (Ellis et al. 2016 : 34). In our study, participants were asked to modify the output of a story that they had previously read. In order to produce counterfactual scenarios, people are constrained to modify one condition from a set of individually necessary and jointly sufficient conditions (Cheng \& Novick 1991). Because of the input text's verbs and semantic roles, we expected some modifications to be operated at the level of agency, transitivity and affectedness. VAC's are expected in this specific context because in the text used as stimulus there is a character that represents the agent of an unhappy outcome (i.e., Mr. Carlson), whereas another character represents the patient of a certain state-of-affairs (i.e., Karen). The polarity of these semantic roles enables a force dynamics' representation (Croft \& Cruse 2004) that may

\footnotetext{
${ }^{7}$ Preceding studies have shown that when processing VACs in L2 English, Spanish learners reflect aspects of their L1 form-meaning mapping (Ellis et al. 2016). In general, features accounting for the typological distance between languages -e.g., the distinction between satellite-framed languages and verb-framed languages- are at the center of attentional processes guided by the learner's L1 salient categories.

${ }^{8}$ In child development research it has been shown that children under 3:0 are capable of making counterfactual predictions related to others (Harris et al. 1996, Reilly 1982) but not related to them (Bates 1976, Reilly 1982). Production data demonstrated that at the age of 4:0 children hardly integrate their counterpart's state-of-knowledge (Champaud et al. 1993). Studies of language comprehension have shown that at the age of 9:0 children still have problems to understand counterfactual sentences in an adult-like way (Amidon 1976).
} 
prompt counterfactual VAC's consisting either to neutralize a patient's feature or to avoid an agent's action.

In the present article, we talk about the agent of an action in a general way as a participant who causes or instigates an event or a change-of-state (Schalley 2004) independently of the participant's volitionality. In this sense, our definition matches with what others scholars name the effector, i.e. the doer of an action, which may or may not be willful or purposeful (Van Valin \& LaPolla 1997). Our analysis takes also into account the role of the patient as the participant who experiences a change-of-state or which is causally affected by another participant (Dowty 1991). In French, a verb denoting the semantic role of the patient is for example subir (undergo), which is lexically related to specific nouns in French, like opération (operation), défaite (defeat), perte (loss), interrogatoire (interrogation), (subir une opération / subir une défaite / subir une perte / subir un interrogatoire, Rey-Debove \& Rey 2004).

\section{The notion of counterfactuality}

Irrealis has traditionally been defined as a subdomain of the hypothetical system. The hypothetical system has been characterized by a wide range of if- clauses going from potentiality to irreality (Comrie 1986, Harris 1986). Depending on the verbal morphology of a given if-clause, the semantic value of the proposition may refer to the unreal non-past (1) or to the unreal past (2).

(1) If he came, he would see me (but he won't)

(2) If he had come, he would have seen me (but he didn't)

In the unreal non-past, the condition if $A$ is not realized at the topic time, nor has it been previously, but it may be in the future, whereas in the unreal past, the condition if $A$ is not realized at the topic time, nor has it been previously and it will not be in the future (Renzi \& Salvi, 1991; Riegel et al., 2001; Grevisse \& Goosse, 2008; Real Academia Española, 2009). In addition to this categorization, there is the distinction between the potential non-past (3) and the potential past (4).

(3) If he were to come, he would see me (he probably won't but he might)

(4) If he were to have come, he would have seen me (maybe he did, maybe he didn't)

This overlapping system combining temporal traits, non-past versus past, and actualization traits, unreal versus potential, has served to explain the development of conditional constructions from Latin to modern Romance languages (Harris 1986 : 268). However, such a categorization does not allow a direct distinction between the potential past (4) and the unreal past (2). This is because the ultimate factor in distinguishing the unreal from the potential is the speaker's state of knowledge. Irreality has been defined as a super-category covering three subdomains: counterfactuality, the non-exclusion-offactuality and non-referentiality (Pietrandrea 2010). Since counterfactuality results from the comparison of reality to an imagined view of what might have been (Kahneman \& Tversky 1982), the certainty of the speaker about the non-realization of the propositional content (Verstraete 2005) seems to be a sine qua non characteristic ${ }^{9}$.

The present study focuses on the Verb-Argument Constructions (VACs) produced to express counterfactual scenarios in L2 French. From a methodological viewpoint, the semantic domain of counterfactuality is an optimal frame to explore VACs because it

9 This idea is at the center of the debate on the appropriateness of the term 'future counterfactuals'. Because the future is due to take place sometime after the topic time, it is considered to be a less well known domain compared to the present or the past (Iatridou 2000, Van linden \& Verstraete 2008). This is why some authors consider it inaccurate to talk about 'future counterfactuals'. 
allows choosing the list of verbs appearing in the stimulus, and so that are likely to be used by the participants. The advantage of exploring VACs within the irrealis domain relies in the cognitive operations of counterfactual thinking (i.e., the comparison between the world as it is and what might have been). Thinking alternative possibilities to factual events or states-of-affairs may imply changes at the level of agency and transitivity that depend on certain verbs or objects. This is the reason why, in the present article, we look at the production of counterfactual scenarios applying a VACs perspective. Our results are based on a well-defined semantic domain which is characterized by (i) the ascription of the learner's responses to the unreal past frame and (ii) the certainty of the speaker about the non-actualization of what has been said. From a semantic viewpoint, counterfactuality combines the apparently contradictory features of potentiality and non-actualization (Versatrete 2005). Counterfactual sentences express something that was desired but did not happen, or an action that was intended but not carried out in the end. Verstraete (2005) refers to them as implicatures of past potentiality.

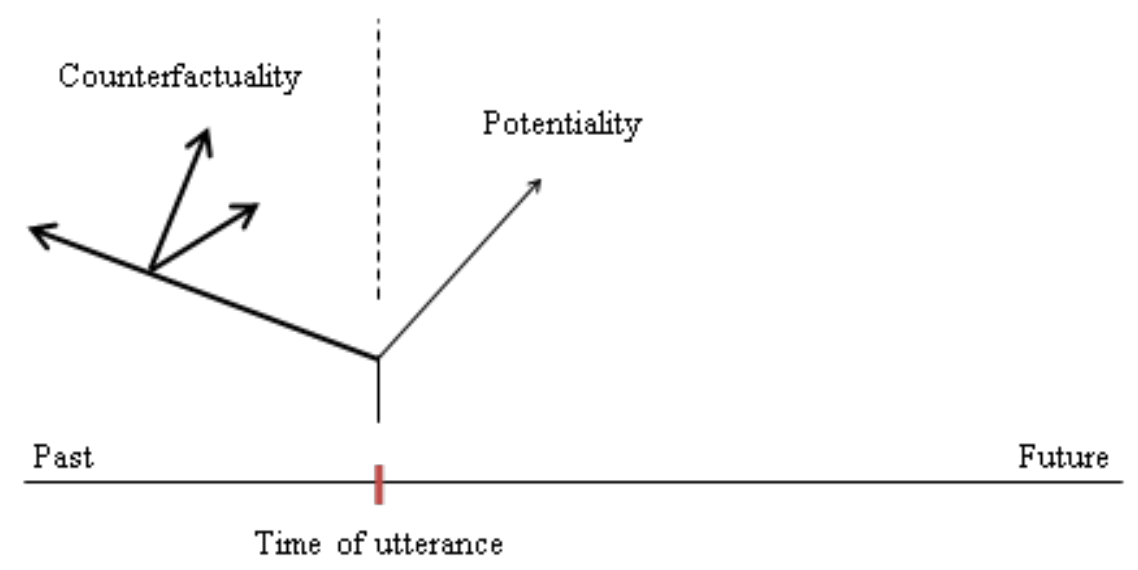

Fig. 1. Graphical representation of other possible worlds.

\section{Participants and methods}

60 subjects took part in our study: 30 native French-speakers and 30 native Spanishspeakers. The participants were recruited at universities, notably from the Law and Arts Faculty at Aix-Marseilles University, in part, from the Maison Méditerranéenne des Sciences de l'Homme (MMSH) and from Marseilles' Medical Faculty ${ }^{10}$. The data was collected mainly at Aix-en-Provence and Marseilles, and to a lesser extent at Nijmegen in the Netherlands ${ }^{11}$. Our study is based upon conversational data gathered in the course of guided interviews. The experiment was conducted once only with native French-speakers and twice for the Spanish speakers: once in FFL and another in their L1 ${ }^{12}$.

\subsection{French-speaking group}

\footnotetext{
10 The students were contacted by circulating Round-Robin e-mail requests to participate. With thanks to Stéphanie Clerc and Daniel Véronique (Aix-Marseilles University) for allowing me to introduce myself, at the beginning of class to their students, and circulate my requests.

${ }^{11}$ The tools for data collection are available on IRIS (iris-database.org).

12 The order for passing FFL-L1 or L1-FFL was randomly attributed (Cf. the Table summarizing Spanish-speaking subjects in the Annexes).
} 
The French control group is comprised of 20 women and 10 men between the ages of 17 and 57. In this group, the individuals' average age was 28.3; they are studying at university. Of the 30 participants, $2 / 3$ are from South-Eastern France -17 from the Provence-Alpes-Côte d'Azur (PACA) region, two moved there as children, and one was born at Nice. The remaining five are from the Paris area, two from Northern France (Normandy, Nord-Pas-de-Calais), two from Eastern France (Burgundy, Franche-Comté) and one from Quebec (cf. Annexe A).

\subsection{Spanish-speaking group}

The Spanish-speaking group is made up of 15 women and 15 men whose age ranges from 21 to 44. The data we present in Tables A \& B (Annexes) have been obtained directly from the participating informants, who filled out a questionnaire ${ }^{13}$. On average, the group's profile corresponds to that of an individual 31.2 of age, studying at university. Of the 30 participants, 16 are Spaniards, 6 Colombian, 5 Mexican, 5 Peruvian and one Chilean. Of the 16 Spaniards, 5 are from the central plateau ( 3 from Madrid and 2 from Valladolid), 4 from the Northern seaboard (two from the Basque Provinces, one from Asturias and one from Cantabria), 3 from the South (two from Seville and one from Murcia) and two from the Eastern seaboard (Valencia). On average they had studied FFL for 5.6 years, with average length of immersion in France being 5.6 years as well.

The group's members are not homogeneously integrated into French society: some informants have chosen to stay in France, others are here only temporarily. Amongst the informants who have lived in France for some time for academic or business reasons, there are Erasmus students (SBJ2, SBJ11, SBJ12 and SBJ13), PhD students on scholarship, who have come to study abroad for three months at most (SBJ7 and SBJ19), an assistant teacher of Spanish Foreign Language (SFL) employed in a Lycée for one school year (SBJ8), and a EFL reader who worked with a University for two school years (SBJ14). Amongst the informants settled in France indefinitely, one finds individuals whose children were born and go to school in France (SBJ3 and SBJ27), or who have sat for State examinations (SBJ17 and SBJ18).

Another factor in relation to heterogeneity within the group is whether or not participants had earlier been exposed to French. Before reaching France, SBJ7 and SBJ10 had, in their country of origin, attended a bilingual school (the Lycée français), while SBJ22 had been in contact with Basque and French since childhood, given how close his place of residence is to France. As for SBJ1, SBJ5, SBJ6, SBJ9, SBJ10, SBJ15, SBJ16, SBJ21, SBJ23, SBJ24, SBJ28 and SBJ30, they were all studying for a Degree (BA, MA, $\mathrm{PhD})$ at French universities, before the recording was made. For 9 informants immersion corresponded to 9 or more years ${ }^{14}$, while for 12 , immersion corresponded to 12 months or

\footnotetext{
${ }^{13}$ In the questionnaire, the participants were asked to state how long they have been studying French. In most cases, the participants added up how many years or months they had taken French lessons in the country of origin (the Spanish-speaker SBJ15 and the Italian-speakers SBJ13, SBJ15, SBJ17 and SBJ22 had never taken French lessons before moving to France). The case of the Spanish-speaker SBJ16 is an exceptional one: he moved to France with his family when he was four, and has studied in France all along. Also exceptional: the case of Italian-speaker SBJ12, who claims to have studied French for 46 years, owing to his personal views on teaching, and on learning an L2 (he teaches his own L1 in France); he sees himself as a curious, self-taught learner, and believes that one is never done with learning.

${ }^{14}$ SBJ3, SBJ16, SBJ17, SBJ18, SBJ22, SBJ24, SBJ27, SBJ29 and SBJ30.
} 
less ${ }^{15}$. As for guided learning in French, the threshold for 8 informants represented 9 or more years' study ${ }^{16}$, while for 5 , the threshold represented one year or less ${ }^{17}$.

\subsubsection{Individual differences}

The Spanish group accounts for a variability of sociolinguistic situations. If we trace two imaginary lines parallel to the $y$-axis and x-axis, we find some points along (cf. Figure 2). This indicates that some learners with little or no training in FFL studies were immersed in France since two years back or more. Conversely, some learners being in France for a period equal or inferior to six months had two, three or four years of FFL studies.

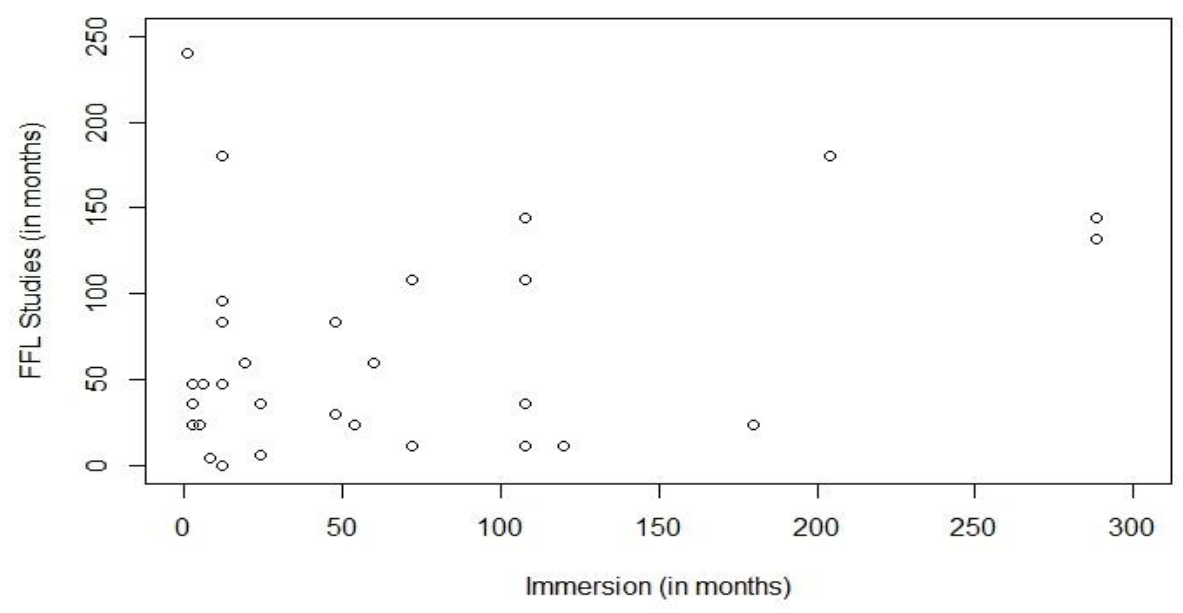

Fig. 2. French L2 sociolinguistic variables across the Spanish group.

In Figure 2 some points form a line that is perpendicular to the $y$-axis and $x$-axis, confirming the presence of experimented learners with exponential values of immersion and FFL studies (subjects 4, 5 and 30). The most experienced learners in terms of immersion are illustrated by two points at the right side of the graphic and correspond to two full-time university professors of Spanish Foreign Language.

\footnotetext{
${ }^{15}$ SBJ1, SBJ2, SBJ7, SBJ8, SBJ9, SBJ10, SBJ11, SBJ12, SBJ13, SBJ15, SBJ19 and SBJ26.

${ }^{16}$ SBJ3, SBJ5, SBJ7, SBJ10, SBJ16, SBJ17, SBJ18 and SBJ30.

${ }^{17}$ SBJ14, SBJ19, SBJ24, SBJ27 and SBJ28.
} 


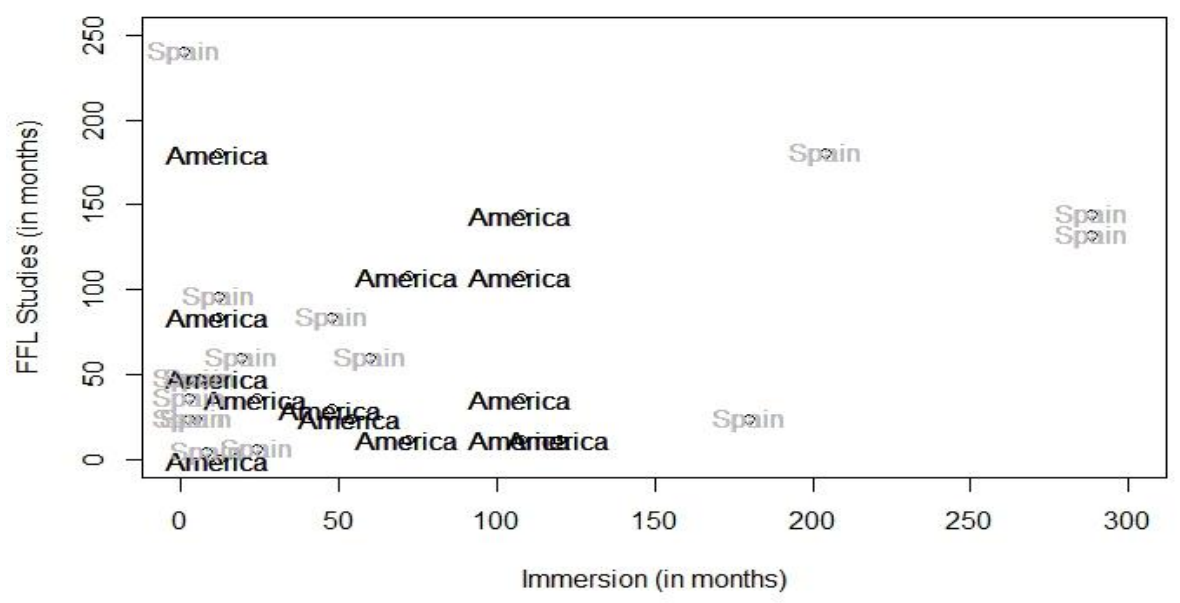

Fig. 3. Varieties of Spanish within the group.

As for the varieties of Spanish spoken within the group, Figure 3 shows the distribution of the learners according to their geographical origins by distinguishing those coming from Latin America or Spain (14 and 16 subjects, respectively). Both subgroups account for a diversity of individual situations.

As for the variable FFL studies, the mean of the Spanish learners is 68.1 months and the amount of dispersion within the group is 61.6. As for the immersion, the mean's group is 67.4 months and the dispersion or standard deviation is 80.6. This means that within the variable immersion there is a greater variation compared to the variable FFL studies. In other words, the data points regarding the learners' amount of FFL studies are clustered more closely around the average than those of the learners' immersion, whose values are spread slightly further from the average.

\subsection{Stimulus and instructions}

For the enquiry's purposes, we have taken as the stimulus a narrative with a causal chain, leading to an unfortunate outcome (Wells \& Gavanski 1989) ${ }^{18}$. Each interview was taped. Once the informant had read the stimulus, we launched the recording. Responses were transcribed using the CLAN editor for Childes. Statistical results were obtained using R from Excel files input data.

The use of a decision-making task seemed to us appropriate to encourage responses from the semantic domain of counterfactuality. The mutation task is a subtype of decisionmaking task ${ }^{19}$ that has been regularly used in the past by a branch of psychological studies interested in the simulation heuristic (Kahneman \& Tvesky 1982, Kahneman \& Miller 1986, Wells \& Gavanski 1989, Miller \& Gunasegaram 1990, Mandel \& Lehman 1996). In general, using a text as stimulus may allow the speaker to anchor its modifications to lexical items contained on it.

\footnotetext{
${ }^{18}$ Wells and Gavanski's original text (1989) was translated from the English, then corrected by two native French-speakers and two native Spanish-speakers (cf. Annexes C for the Spanish version and $\mathrm{D}$ for the original text in English).

${ }^{19}$ Because of their open nature -i.e., many solutions can be provided-, decision-making tasks are more cognitively demanding that narrative tasks, in which speakers are given a clear storyline (Gilabert et al. 2011).
} 


\section{$\underline{\text { Stimulus }}$}

Karen était assistante à l'édition dans une petite agence de publicité. Elle avait une rare maladie héréditaire, l'hemotrisoma de Karpinson, caractérisée par le manque d'une enzyme qui normalement divise certaines protéines du système digestif. En raison de cela les boissons fermentées comme le vin ou les liqueurs pouvaient lui causer des sévères réactions allergiques.

Karen avait eu une promotion dans son travail et son supérieur, monsieur Carlson, l'avait emmenée dans un restaurant français plutôt cher pour l'y fêter. Etant donné que monsieur Carlson avait mangé plusieurs fois dans ce restaurant il commanda pour les deux. Pendant qu'il regardait le menu il considérait quel plat commander pour Karen. Il pensa d'abord aux coquilles Saint-Jacques mais au dernier moment il choisit les moules marinières. Monsieur Carlson ne le savait pas mais les moules marinières étaient cuites dans une sauce à base de vin tandis que les coquilles Saint-Jacques ne contenaient pas de vin.

Karen savoura son plat mais elle commença à se sentir mal peu après avoir fini. Quelques minutes plus tard elle souffrit de convulsions et elle fut transportée en ambulance. En chemin pour l'hôpital elle mourut.

$\underline{\text { Instruction }}$

Proposez trois modifications qui auraient pu empêcher la mort de Karen et expliquez pourquoi elles auraient empêché sa mort.

Our study is based on the assumption that some of the lexical items appearing in the stimulus relate to a certain syntax property among transitivity, agentivity or affectedness. For example, the verbs commander (to order) and décider (to decide on) may refer to an accusative or direct object explicitly named in the sentence or implicitly understood while reading. In the stimulus above the verb commander (to order) may affect two different accusatives -i.e., the Moules Mariniere or the Coquilles Saint-Jacques-, and affecting one of them excludes the other (either the Moules or the Coquilles were ordered for Karen; never both of them). Because of this exclusion between the direct objects pertaining to the verbs commander (to order) and décider (to decide on), any mutation related to these items will be based on the algebraic operator 'otherwise' $\left(\mathrm{W}_{0}=\right.$ to order the Moules; otherwise $\mathrm{W}_{1}=$ to order the Coquilles). The same operator pertains to other potential mutations based either on agentivity $\left(\mathrm{W}_{0}=\mathrm{Mr}\right.$. Carlson orders; otherwise $\mathrm{W}_{1}=$ Karen orders $)$ or affectedness $\left(\mathrm{W}_{0}=\right.$ Karen had a condition; otherwise $\mathrm{W}_{1}=$ Karen had not a condition). As mentioned in Section 2 our hypothesis is that at this procedural level L1 and L2 groups will behave similarly. ${ }^{20}$

\section{Results}

We will henceforth distinguish the dictum -i.e., the stimuli's variable to which the informational content applies- and the modus -i.e., the way in which the conceptualization of such information is realized. The distinction between the dictum and the modus has been

\footnotetext{
${ }^{20}$ Our analysis is inspired in the notion of 'access to information' explained by Tournadre \& LaPolla (2014). In their survey on evidentiality, these authors make a distinction between on the one hand the 'source of information' which is primarily verbal and on the other hand the 'access to information' which is the subjective strategy of the speaker in representing a particular state-of-affairs and refers to non-verbal cues (e.g., sensory, inferential). In our mutation task, the source of information corresponds to the textual units of the stimulus. The responses to the mutation task will be analyzed as instances revealing the speaker's 'access to information'. Thus, attention will be paid on deconstructing the speaker's access to counterfactual scenarios via the syntactic operations made on transitivity, agentivity and affectedness.
} 
previously used in the field of language acquisition to explore the expression of epistemic modality by children (cf. Champaud et al. 1993). However, in our study this taxonomy does not exactly apply to the same notions as in Champaud's et al (1993).

\subsection{The dictum}

For both groups, the most frequently modified variable was the one related to the dish. For the control group, dish modifications represented 50\% over the 90 responses elicited, whereas for the L2 speakers it represented 44\%. The second variable more frequently modified was the one related to Karen's allergy, which represented $29 \%$ of the control group responses and $21 \%$ of the L2 French responses. The variable related to Karen's promotion was equally modified, representing $8 \%$ for each group. Chi-squared analyses revealed no significant differences between groups in the distribution of their modifications across variables. In all, $86 \%$ of the modifications operated by the control group and $73 \%$ of the modifications operated by the L2 French group applied to any of the mentioned variables in the input (Allergy / Dish / Promotion).

In L1 Spanish, $41.1 \%$ of the counterfactual modifications applied to the Dish variable (37 out of 90 responses), followed by $17.7 \%$ applying to the Allergy variable (16 responses), and by $10 \%$ applying to the Promotion variable ( 9 responses). We cannot exclude a re-test effect in these figures, since the production in L1 Spanish was obtained from the same group of speakers that produced the L2 French data. As mentioned in the Annexes, the order of the language input $-\mathrm{FFL} / \mathrm{L} 1$ or $\mathrm{L} 1 / \mathrm{FFL}-$ was randomly assigned across the native Spanish-speaking participants (cf. Table 2). Chi-squared analyses did not reveal significant differences between the distribution provided in L1 Spanish compared to the control group, $X(2, \mathrm{~N}=90), p=0.1$ for the Allergy variable, $X(2, \mathrm{~N}=90), p=0.2$ for the Dish variable, $X(2, \mathrm{~N}=90), p=0.7$ for the Promotion variable.

Table 2. Distribution of the modified variables per group $(n=90)$.

\begin{tabular}{|c|c|c|c|}
\hline & $\begin{array}{l}\text { Control } \\
\text { group }\end{array}$ & $\begin{array}{c}\text { L2 } \\
\text { French }\end{array}$ & $\begin{array}{c}p \text {-values } \\
X^{2} \text { Test }\end{array}$ \\
\hline Allergy & $\begin{array}{c}26 \\
28.8 \%\end{array}$ & $\begin{array}{c}19 \\
21.1 \%\end{array}$ & 0.3 \\
\hline Dish & $\begin{array}{c}45 \\
50 \%\end{array}$ & $\begin{array}{c}40 \\
44.4 \% \\
\end{array}$ & 0.5 \\
\hline Promotion & $\begin{array}{c}7 \\
7.7 \% \\
\end{array}$ & $\begin{array}{c}7 \\
7.7 \% \\
\end{array}$ & 1 \\
\hline Subtotal & $\begin{array}{c}78 \\
86 \% \\
\end{array}$ & $\begin{array}{c}66 \\
73 \% \\
\end{array}$ & \\
\hline
\end{tabular}

\subsection{The modus}

Among the possible conceptualizations playing a role in the Gestalt, our analysis of the semantic processing is framed within the force dynamics (Croft \& Cruse 2004). The force dynamics' model is based on the notion of causality in which processes concern different types of forces operating differently onto the participants. Our description of the modus is based on the modifications made to the semantic roles applying in the stimulus. When comparing the factual world $\left(\mathrm{W}_{0}\right)$ to what might have been $\left(\mathrm{W}_{1}\right)$, speakers may lead different operations at the level of different semantic roles. Table 3 shows that counterfactual scenarios may be the result of attributing the agent role of an action to someone else, replacing one accusative by another or neutralizing someone's attributes. The latter operation can be made by transforming an originally affirmative sentence in a negative one (cf. Patient). The former operations can be lead exchanging lexical items (cf. 
Agent \& Accusative). The VACs produced by speakers in the aim of providing alternative scenarios $\left(\mathrm{W}_{1}\right)$ to the factual world of the stimulus $\left(\mathrm{W}_{0}\right)$ presented regularities that are henceforth considered as patterns. The most frequent counterfactual VAC obtained in both groups was encoded by the structure Verb-Object by means of the lexical items ChoisirPlat, (To choose-Dish), Commander-Plat (To order-Dish), and Demander-Plat (To askDish), followed by the pattern Verb-Objet-Dative by means of the lexical items DireAllergie-Chef (To say-Allergy-Boss) and Prévenir-Allergie-Chef (To warn-Allergy-Boss). Beyond these VACs, the modus of the control group and the L2 French speakers differed.

In the next sections, our results are organized by the stimulus' variables more frequently modified by speakers (i.e., Dish / Allergy / Promotion). The lists of verbs used to modify these variables are presented in sections 6.6 .1 to 6.6.3. The syntactic operations enabling the production of counterfactual scenarios are presented in sections 6.3 to 6.5 .

Table 3. Modifications operated at the level of the semantic roles.

\begin{tabular}{|l|l|l|}
\cline { 2 - 3 } \multicolumn{1}{c|}{} & Stimulus $\left(\mathbf{W}_{\mathbf{0}}\right)$ & Counterfactual scenario $\left(\mathbf{W}_{\mathbf{1}}\right)$ \\
\hline $\begin{array}{l}\text { Agent } \\
\text { (Agentivity) }\end{array}$ & $\begin{array}{l}\text { Carlson choisit le menu } \\
\text { Mr. Carlson choses the menu }\end{array}$ & $\begin{array}{l}\text { Karen choisit le menu } \\
\text { Karen choses the menu }\end{array}$ \\
\hline $\begin{array}{l}\text { Accusative } \\
\text { (Transitivity) }\end{array}$ & $\begin{array}{l}\text { Carlson choisit les moules } \\
\text { Mr. Carlson choses the mussels }\end{array}$ & $\begin{array}{l}\text { Carlson choisit les Saint-Jacques } \\
\text { Mr. Carlson choses the scallops }\end{array}$ \\
\hline $\begin{array}{l}\text { Patient } \\
\text { (Affectedness) }\end{array}$ & $\begin{array}{l}\text { Karen a une maladie rare } \\
\text { Karen has a rare disease }\end{array}$ & $\begin{array}{l}\text { Karen n'a pas } \text { de maladie rare } \\
\text { Karen does not have a rare disease }\end{array}$ \\
\hline
\end{tabular}

\subsection{Syntactic operations for the Dish variable}

The modifications made to the Dish variable were based on syntactic operations applying either to the agent or the accusative. The Dish modifications operated at the agent level consisted to say that it was Karen -instead of Carlson- to have chosen her own menu (Elle aurait pu choisir les Saint-Jacques; She could have chosen the scallops). Those operated at the accusative level consisted to say that the chosen dish was not the mussels but instead the scallops (Il aurait pu choisir les Saint-Jacques; He could have chosen the scallops). The distribution of these syntactic operations appeared to be balanced within each group. The examples appearing in Table 4 come from the control group.

In L1 Spanish, 37 modifications were related to the Dish variable. 19 applied to the semantic role of the agent and 18 to the accusative.

Table 4. Distribution of the modifications targeting the Dish variable.

\begin{tabular}{|l|c|c|l|}
\cline { 2 - 4 } \multicolumn{1}{c|}{} & $\begin{array}{c}\text { Control } \\
\text { group }\end{array}$ & $\begin{array}{c}\text { L2 } \\
\text { French }\end{array}$ & Examples \\
\hline Agent & 23 & 20 & $\begin{array}{l}\text { Elle } \text { aurait pu choisir son plat toute seule } \\
\text { She could have chosen the scallops }\end{array}$ \\
\hline Accusative & 21 & 17 & $\begin{array}{l}\text { Il aurait pu choisir les Saint-Jacques } \\
\text { He could have chosen the scallops }\end{array}$ \\
\cline { 2 - 5 } & $44^{23}$ & $37^{24}$ & \multicolumn{2}{c}{} \\
\cline { 2 - 4 } & &
\end{tabular}

\subsection{Syntactic operations for the Allergy variable}

\footnotetext{
${ }^{21}$ Control group SBJ1\#3.

${ }^{22}$ Control group SBJ6\#1.

${ }^{23}$ One occurrence excluded because not operating on the agent nor the accusative (SBJ26\#1).

${ }^{24}$ Three occurrences excluded because not operating on the agent nor the accusative (SBJ11\#3, SBJ12\#2, SBJ29\#2).
} 
The modifications made to the Allergy variable were based on syntactic operations applying either to the patient or the accusative. The former consisted to say that Karen was not suffering from a rare condition, as opposed to the stimulus story (Elle aurait pu ne pas etre allergique; She could have not being allergic). The latter consisted to say that Karen did warn Carlson about her intolerance to fermented drinks, which was something she omitted in the stimulus story (Karen préviens Carlson de sa maladie; Karen warns Carlson about her condition). The distribution of these syntactic operations was similar across the groups, being the scenario of reporting the illness more frequently activated than the scenario where Karen does not suffer from a rare condition. The examples shown in Table 5 were produced by native French speakers.

In L1 Spanish, 16 modifications were related to the Allergy variable. 11 applied to the accusative and 5 to the patient.

Table 5. Distribution of the modifications targeting the Allergy variable.

\begin{tabular}{|l|c|c|l|}
\cline { 2 - 4 } \multicolumn{1}{c|}{} & $\begin{array}{c}\text { Control } \\
\text { group }\end{array}$ & $\begin{array}{c}\text { L2 } \\
\text { French }\end{array}$ & Examples \\
\hline Patient & 9 & 7 & $\begin{array}{l}\text { Elle aurait pu ne pas être allergique } \\
\text { She could have not being allergic }\end{array}$ \\
\hline Accusative & 17 & 12 & $\begin{array}{l}\text { Karen aurait pu prévenir son supérieur de son allergie } \\
\text { Karen could have warned her boss about her condition }\end{array}$ \\
\hline & 26 & 19 & \multicolumn{1}{|c}{} \\
\cline { 2 - 4 } & & &
\end{tabular}

\subsection{Syntactic operations for the Promotion variable}

All the modifications made to the Promotion variable were based on syntactic operations involving affectedness. The counterfactual scenarios provided by participants consisted to say that Karen had not been promoted, unlikely what expressed in the stimulus (Elle aurait pu ne pas être promue; She could have not being promoted). Modifications related to the Promotion variable represented roughly $8 \%$ in each group, being the less modified variable within the $\mathrm{W}_{0}$ set Allergy / Dish / Promotion (cf. Table 2). This was also the case in L1 Spanish, where 9 modifications targeted the Promotion variable.

Table 6. Syntactic operations across the modified variables.

\begin{tabular}{|l|c|c|c|}
\cline { 2 - 4 } \multicolumn{1}{c|}{} & $\begin{array}{c}\text { Control } \\
\text { group }\end{array}$ & $\begin{array}{c}\text { L2 } \\
\text { French }\end{array}$ & $\begin{array}{c}\boldsymbol{p} \text {-values } \\
\boldsymbol{X}^{2} \text { Test }\end{array}$ \\
\hline Agent (n=43) & 23 & 20 & 0.7 \\
\hline Dish & 21 & 17 & 0.5 \\
\hline Accusative (n=67) & 17 & 12 & 0.4 \\
\hline Dish & 9 & 7 & 0.7 \\
\hline Allergy & 9 & 7 & 1 \\
\hline Patient (n=30) & 7 & \multicolumn{1}{|l}{} \\
\hline Allergy & &
\end{tabular}

\footnotetext{
${ }^{25}$ Control group SBJ6\#3.

${ }^{26}$ Control group SBJ27\#1.
} 
Table 6 shows no significant differences between groups in the syntactic operations pertaining to the items Dish / Allergy / Promotion. This suggests that natives and L2 French speakers behave similarly from a procedural viewpoint to the mutation task.

\subsection{Repertoires of lexical verbs}

The verbs associated to a given variable were analyzed in order to know whether the lexical lists produced by the control group and the L2 speakers differed. First, we will pay attention to the list prompted by the Dish variable, which was the most modified variable in both groups (section 6.6.1). Secondly, we will present the lists of repertoires targeting the variables Allergy and Promotion (sections 6.6.2 and 6.6.3, respectively). Within each variable, verbs are presented in separate sets depending on the linguistic property they modify (i.e., agentivity, transitivity or affectedness).

\subsection{List of verbs targeting the Dish variable}

In all, 85 modifications targeted the Dish variable. 40 were produced by the learners' group and 45 by the control group. In L2 French, 55\% of the modifications targeting the Dish variable carried any of the dynamic verbs choisir, commander, demander (to choose, to order, to request). In the control group, these verbs were used in $64.4 \%$ of the modifications targeting the Dish variable. Concerning the use of these verbs in logical operations involving agentivity and transitivity similar distributions were observed in L1 and L2 French for the verbs choisir and commander (to choose, to order) but not for the verb demander (to ask), (cf. Table 7).

Table 7. List of verbs modifying the Dish variable $(n=85)^{27}$.

\begin{tabular}{|c|c|c|c|}
\hline & $\begin{array}{l}\text { Control } \\
\text { group }\end{array}$ & $\begin{array}{c}\text { L2 } \\
\text { French }\end{array}$ & Examples \\
\hline \multicolumn{4}{|c|}{ Agentivity $(\mathrm{n}=43)$} \\
\hline $\begin{array}{l}\text { Choisir } \\
(15)\end{array}$ & 9 & 6 & $\begin{array}{l}\text { Elle aurait pu choisir toute seule son plat }{ }^{28} \\
\text { She could have chosen her own dish }\end{array}$ \\
\hline $\begin{array}{l}\text { Commander } \\
(7)\end{array}$ & 4 & 3 & $\begin{array}{l}\text { Si Karen commandait son propre repas }{ }^{29} \\
\text { If Karen ordered her own dish }\end{array}$ \\
\hline $\begin{array}{l}\text { Demander } \\
(5)\end{array}$ & 4 & 1 & $\begin{array}{l}\text { Elle aurait dî demander au serveur la composition du plat }{ }^{30} \\
\text { She should have asked the dish's ingredients to the waiter }\end{array}$ \\
\hline \multicolumn{4}{|c|}{ Transitivity $(n=38)$} \\
\hline \begin{tabular}{|l|l} 
Choisir \\
$(11)$
\end{tabular} & 6 & 5 & $\begin{array}{l}\text { Il aurait pu choisir les Saint-Jacques } \\
\text { He could have chosen the scallops }\end{array}$ \\
\hline $\begin{array}{l}\text { Commander } \\
\text { (7) }\end{array}$ & 4 & 3 & $\begin{array}{l}\text { Monsieur Carlson aurait dî commander les Saint Jacques } \\
\text { Mr. Carlson should have ordered the scallops }\end{array}$ \\
\hline $\begin{array}{l}\text { Demander } \\
(6)\end{array}$ & 2 & 4 & $\begin{array}{l}\text { Il aurait demandé si les repas avaient ou pas de vin } \\
\text { He would have asked whether the dishes had any wine }\end{array}$ \\
\hline
\end{tabular}

\footnotetext{
${ }^{27}$ Four occurrences excluded because not operating on the agent nor the accusative (SBJ26\#1 from the control group, and SBJ11\#3, SBJ12\#2, SBJ29\#2 from the learners' group).

${ }^{28}$ Control group SBJ6\#2.

${ }^{29}$ Control group SBJ14\#1.

${ }^{30}$ Control group SBJ8\#2.

${ }^{31}$ Control group SBJ6\#1.

${ }^{32}$ Control group SBJ7\#2.

${ }^{33}$ Learner SBJ10\#3.
} 
In all, French natives produced more conceptualizations based on reversals at the level of the agent, compared to L2 speakers. One possible interpretation is to consider Spaniard native speakers as more indulgent concerning the decision-role of Mr. Carlson over Karen's menu. Conversely, one might see French speakers as more concerned by Karen's passiveness. The small size of our sample make impossible to confirm this observation by quantitative methods. In Table 7, five examples come from the control group and one from the group of learners.

In L1 Spanish, the more frequent verbs were pedir (to order) with 12 occurrences, preguntar (to ask) with 7 occurrences, elegir (to choose) with 3 occurrences and the infinitive periphrasis dejar pedir (to let ordering) with also 3 occurrences. It is interesting to note that the Dish variable recall verbs with equivalent meanings in French and Spanish: commander / pedir (to order), preguntar / demander (to ask), choisir / elegir (to choose). It can be claimed that this result might be influenced by a retest effect in the Spanish participants who were interviewed twice, first in their L1 and then in L2 French or vice versa $^{34}$. We will come back to this idea further in the Discussion (section 7).

\subsubsection{List of verbs targeting the Allergy variable}

The variable Allergy was modified in 45 counterfactual responses. The group of learners produced 19 and the control group produced 26. As mentioned in section 6.4, the modifications made to the Allergy variable were based on syntactic operations applying either to the patient (16 responses) or the accusative (29 responses). Concerning the list of verbs operating at the level of the accusative the control group and the learners' group produced similar outputs (cf. Table 8). In both groups the more frequent verbs were dire (to tell, 4 occurrences each) and prévenir (to inform, 3 occurrences each). Despite of similar distributions, the list of verbs produced by the control group was lexically richer, with verbs that did not emerge in the learners' production such as avertir (to warn, 2 occurrences), signaler (to report), tenir au courant (to keep informed) or spécifier (to state). Unlikely, the verb parler (to talk) was produced by both groups ( 2 occurrences found in the control group and one in the group of learners). The examples reported in Table 8 came from native French speakers.

Table 8. List of verbs modifying the Allergy variable $(n=45)$.

\begin{tabular}{|c|c|c|c|}
\hline & $\begin{array}{l}\text { Control } \\
\text { group }\end{array}$ & $\begin{array}{c}\text { L2 } \\
\text { French }\end{array}$ & Examples \\
\hline \multicolumn{4}{|c|}{ Affectedness $(n=16)$} \\
\hline \begin{tabular}{|l|} 
Etre \\
$(8)$
\end{tabular} & 7 & 1 & $\begin{array}{l}\text { Elle aurait pu ne pas être allergique } \\
\text { She could have not being allergic }\end{array}$ \\
\hline \begin{tabular}{|l|} 
Avoir \\
$(8)$
\end{tabular} & 2 & 6 & $\begin{array}{l}\text { Elle aurait pu ne pas avoir de maladie héréditaire rare } \\
\text { She could have not had a rare condition }\end{array}$ \\
\hline \multicolumn{4}{|c|}{ Transitivity $(\mathrm{n}=29)$} \\
\hline $\begin{array}{l}\text { Dire } \\
(8)\end{array}$ & 4 & 4 & $\begin{array}{l}\text { Elle aurait dî le dire dans son travail }{ }^{37} \\
\text { She should have tell it at work }\end{array}$ \\
\hline $\begin{array}{l}\text { Prévenir } \\
(6)\end{array}$ & 3 & 3 & $\begin{array}{l}\text { Karen aurait pu prévenir son supérieur de son allergie } \\
\text { Karen could have informed her boss about her condition }\end{array}$ \\
\hline
\end{tabular}

\footnotetext{
${ }^{34}$ Language configuration was assigned in a random order across participants (cf. Summary of Spanish-speaking participants in the Annexes).

${ }^{35}$ Control group SBJ6\#3.

${ }^{36}$ Control group SBJ1\#1.

37 Control group SBJ13\#2.

38 Control group SBJ27\#1.
} 
As for the list of verbs modifying the patient's affectedness, distributional differences were found concerning the state verbs être (to be) and avoir (to have). In L2 French, the more frequent verb used to modify the patient's affectedness was avoir (6 occurrences), whereas the control group preferred etre ( 7 occurrences). This preliminary result can be interpreted as if each group favored a different prominent representation: 'being ill' in the case of the control group and 'having an illness' in the case of the learners' group.

\subsubsection{List of verbs targeting the Promotion variable}

In L2 French, the modifications made to the Promotion variable carried dynamic verbs such as recevoir (to receive, 2 occurrences), donner (to give, one occurrence) and devenir (to become, one occurrence). The state verb avoir (to have) was found in two occurrences. Unlikely, the control group strictly used state verbs to modify the Promotion variable, with 6 occurrences carrying the verb avoir (to have) and one occurrence carrying the verb être (to be). The small size of our sample concerning the Promotion variable does not allow us to make any conclusion here. However, the use of both dynamic verbs and state verbs by the learners' group, and the strictly use of state verbs by the control group seems to us an interesting result that merits to be further explored. One possible interpretation may be that the conceptualization of the item Promotion is [+ durative] for the control group and [+ punctual] for the Spanish learners, as if French speakers represented themselves as 'being promoted' and the Spanish learners as 'becoming promoted'. The production of an achievement verb to refer to the item Promotion by Spaniards might be explained by a transfer related to aspectual semantics. Situations including an inherent endpoint may be expressed in Spanish by verbs as 'to give' or 'to obtain' (dar, obtener), rather than 'to have' (tener). A durative kind of situation normally requires the use of a durative situation verb phrase, while a punctual kind of situation always require the use of a punctual situation verb phrase (Declerck 2006). Is the item ascenso (promotion) more frequently combined in Spanish with accomplishment verbs rather than sate verbs? Further studies should answer this question in order to confirm an eventual influence of L1 in L2 form-function mapping.

\section{Discussion}

Our results so far have pointed out two layers of language's architecture: one superficial level that accounts for the grammatical devices used in French (i.e., the modus, in our terminology), and one deeper level that accounts for the logical operations based on the agent, the direct object or the patient (i.e., the dictum). In the present section, we will answer some questions presented at the beginning of this article (cf. section 2).

\subsection{Lack of significant differences in the dictum}

Although preliminary, our results confirmed that logical operations on semantic roles were similarly distributed across L1 and L2 speakers. This means that the cognitive principles yielding the simulation heuristic (Kahneman \& Tversky 1982) also apply in L2 productions. The role of the input language in decision-making tasks has been widely discussed by psychologists. In particular, decision-making has been shown to be modulated by the language in which a problem is presented in contexts involving a high emotional connotation (Keysar et al. 2012). In decision making under uncertainty, the use of a foreign language has proved to promote consistent choices and to reduce ambiguity aversion (Costa et al. 2014). The conclusions of these studies confirmed behavioral differences between L1 
and L2 populations. Our results should not be read under behavioral considerations but from a procedural-knowledge perspective.

The stimulus's variables more frequently modified were equally distributed within groups, being the most recent event presented in the input, the most targeted by both populations (i.e., Carlson's decision on the dish). This result can be explained by the principle observed by Miller \& Gunasegaram (1990) which predicts that, when confronted to two independent states-of-affairs, people tend to blame the agent having more recently intervened. In a more general way, the lack of differences in the outcomes produced by the control group and the learners' group proved the robustness of the principles guiding mental simulation beyond the use of SL.

VACs involving affectedness and transitivity were based on the use of identical grammatical features in L2 and L1. VACs relating to affectedness were realized by static verbs in negative assessments (e.g., Elle aurait pu ne pas être allergique; She could have not being allergic), whereas VACs relating to transitivity were realized by dynamic verbs in affirmative assessments (e.g., Il aurait pu choisir l'autre plat; He could have chosen the other dish).

An explicative factor for the lack of differences between L2 and L1 speakers at the level of the dictum may be related to the imbricate relationship between semantics and the maturation constraints allowing the representation of causality. Spatial, temporal and object permutations are cognitive prerequisites to further integrate the abstract notions of causality and counterfactuality (Piaget 1963). Preceding literature on language acquisition has shown that both production and comprehension are conditioned by maturation constraints (Amidon 1976, Bates 1976, Reilly 1982, Champaud et al. 1993, Harris et al. 1996). The properties operating at the level of VACs - e.g., agentivity, transitivity, affectedness- are thus likely to be at the center of the mental representations involving causality and thus, they are likely to belong to a deeper layer of language compared to lexical or grammatical realizations.

\subsection{Lexical realizations of noun-verb constructions}

VACs modifying the patient's affectedness -i.e., Karen suffering from a rare conditionrevealed differences between the control group and the learners' group concerning the use of state verbs. In L2 French, avoir (to have) was preferred over être (to be), whereas in the production of the control group être was more frequent than avoir (cf. Table 8). These preferences may reflect different prominent representations for each group. Does this mean that the idea of 'being ill' is more frequently activated compared to the idea of 'having an illness', in the mind of native French speakers? The small size of our sample does not allow us to make any conclusion of this sort. Interestingly, another conceptualization that revealed differences between the control group's production and the L2 French's was again related to the patient's affectedness -this time, Karen being promoted-. Here the counterfactual modifications produced by the control group carried strictly state verbs, whereas the repertoire in L2 French contained either dynamic or state verbs. In L1 French the expression 'to have a promotion' (avoir une promotion) was prominent. Unlikely, in L2 French the repertoire of verbs was greater but none of them had more than 2 occurrences. This may suggest that the noun-verb constructions prompted by the variable Promotion were less familiar to the L2 learners compared to the noun-verb constructions prompted by the variable Dish. VAC's modifying the agent's role or replacing the input's accusative by another revealed no differences between groups. As for the variable Dish, the most frequent verbs in both groups were to choose, to order, and to ask (choisir, commander, demander).

Previous studies have shown that the L2 acquisition of VACs is affected by frequencies in natural language usage, by their prototypicality, and by their contingency of form- 
function mapping (Ellis et al. 2016: 217). Our results suggest that the lexicalized patterns within VACs modifying the patient's affectedness are less familiar to learners than those modifying transitivity and agency. The syntactic operations operated on affectedness have shown some divergences in the lexical realizations of verb-noun constructions in L1 and L2 for (i) state verbs -i.e., avoir versus être- expressing someone's condition, and between (ii) accomplishment verbs and the state verb avoir when expressing someone's promotion.

Certain salient features in the L1 have proven to have an impact in L2 conceptualizations (Slobin 1996, Carroll et al. 2012, Hung 2012) especially when the languages involved hold typological differences (e.g., verb-framed languages like French or Spanish versus satellite-framed languages like German or English). The lexical preferences of Path shown by Japanese learners of English indicated a pattern that resembled a gradual convergence between the L1 and the L2 (Brown \& Gullberg 2011). These authors observed that the distribution of verbs and adverbials in the L2 production was midway between source and target languages. It would be interesting to integrate our preliminary results on affectedness in the design of future methods to further explore the lexicalized patterns in the semantic domain of counterfactuality.

\subsection{The impact of L2 proficiency in the modus}

In section 5.2.1 we have presented some individual differences between learners that testimony of the group's heterogeneity. The learners' differences regarding the time of immersion in France and the time of FFL studies may explain the dissimilarities at the level of their L2 proficiency. As for the modus, some grammatical features appeared not to be native-like integrated in the L2 system of some learners. This was the case for the realization of negative sentences involving the passé composé for one Spanish learner accounting for 3 months of immersion and 4 years of FFL studies at the time of the data collection (SUBJ2). The French negative marker pas -which is canonically used between the auxiliary verb and the past participle- was sometimes omitted (e.g., Monsieur Carlson n'y a pas d'argent, il n'a pu inviter à le restaurant à Karen) or produced after the past participle (e.g., Karen ne a pas mort parce qu'elle ne a mangé pas la sauce à base de vin de les moules). Other inconsistences related to the segments reported above are (i) the lack of systematic contracted forms involving the negative marker ne when followed by the auxiliary avoir (i.e., elle n'a pas mangé); (ii) the non-native use of the auxiliary avoir to express the accomplishment of someone's decease; and (iii) the non-concordance of the past participle with the subject's gender (i.e., elle est morte). These observations make us consider the proficiency level of SBJ2 as relatively less advanced compared to other learners. Beyond this particular case, the group of learners proved to have a relatively complex verbal morphology to express counterfactuality in L2 French that accounted for forms of the past conditional, the plus-que-parfait and the present subjunctive (cf. Repiso 2014: 262-263). No significant differences were found between the learners coming from Latin America and those coming from Spain for the distribution of the grammatical means used to encode counterfactuality in Spanish (cf. Repiso 2013: 104).

The combination of a past conditional and a modal verb (e.g., elle aurait pu/dh, she could/should have + past participle) was the most frequent grammatical device used by native French speakers to encode counterfactual scenarios, representing 35\% of the 90 responses. In L2 French, this combination was found in $16 \%$ of the scenarios provided by 10 Spanish-speaking participants. 5 of these participants worked in France from at least 9 years $(\mathrm{SBJ} 3, \mathrm{SBJ} 16, \mathrm{SBJ} 18, \mathrm{SBJ} 27, \mathrm{SBJ} 30)^{39}$ and thus, are represented at the right side of

${ }^{39}$ Two of these participants were from Spanish, one from Mexico, one from Colombia, and one from Peru. 
Figures $2 \& 3$ (section 5.2.1). This suggests that the most experienced speakers in terms of immersion are more likely to express themselves in a native-like manner compared to the rest of the group. Two reasons can explain this advantage. First, they are exposed to a large amount of input from the irrealis semantic domain. Second, they have more opportunities to perceive frequency-biased regularities, like the use of modal markers $p u / d \hat{u}$ to express what might have been in French. In the Spanish learners' group, 9 participants presented an immersion in France higher or equal to 9 years (cf. section 5.2) but only 5 of them produced the modalized conditional that prominently characterized the productions of the native French speakers. The other 5 Spanish-speaking participants having produced the modalized conditional presented heterogeneous profiles concerning the time of immersion in France going from 5 months to 4.5 years- and the time of FFL studies, going from 6 months to 15 years. These 5 participants are represented somewhere in the left side of Figures $2 \& 3$ among other unexperienced learners (section 5.2.1). This observation suggests that individual differences linked to psychological traits or factors as motivation are equally important to explain L2 proficiency as immersion or FL studies.

\section{Conclusion}

We hope to have drawn attention on semantics as a depth-level of language less permeable to L2 language-based differences. The preliminary results presented in this article revealed no significant differences between L2 and L1 speakers for the dictum-i.e., the stimulus's variable to which the informational content applies- but they did for the modus -i.e., the way in which the conceptualization of such information is realized-. $86 \%$ of the modifications operated by the control group and $73 \%$ of the L2 French group resulted from restoring the normal value of a variable rather than from introducing unlikely events. This result is coherent with the cognitive principle of simulation heuristic formulated by psychologists Daniel Kahneman and Amos Tversky (1982). As for the lexical realizations concerning noun-verb constructions, qualitative differences were found between L2 learners and the control group. The former used either dynamic verbs or state verbs to modify the input's variable Promotion, whereas the later strictly used state verbs. This might be explain because the mental representations prompted by the item Promotion, which seems to be [ + durative] for the control group and [+ punctual] for the learners' group. It has been argued that the L2 VACs may be influenced by the aspectual semantics of the equivalent noun in L1 Spanish (ascenso, promotion) and the nature of the verbs more frequently associated to it (i.e, dynamic verbs such as dar or obtener, to give, to obtain). Further research targeting a greater number of participants and languages should confirm the preliminary results presented here.

\section{Acknowledgements}

I express my gratitude to the organizers of the conference Knowledge and Usage in Second Language, where these results were first presented (University of Nantes, 2016 June $29^{\text {th }}-$ July $1^{\text {st }}$ ). Thanks to the scientific committee and to the anonymous reviewers for their insightful comments and suggestions.

\section{References}


Amidon, A. (1976). Children's Understanding of Sentences with Contingent Relations: Why Are Temporal and Conditional Connectives so Difficult? Journal of Experimental Child Psychology 22, 423-437.

Bates, E. (1976). Language and Context: The Acquisition of Pragmatics. New York: Academic Press.

Brown, A., Gullberg, M. (2011). Bidirectional cross-linguistic influence in event conceptualization? Expressions of Path among Japanese learners of English. Bilingualism: Language and Cognition 14 (1), 79-94. DOI: 10.1017/S1366728910000064.

Carroll, M., Weimar, K., Flecken, M., Lambert, M., Stutterheim, C. von. (2012). Tracing trajectories. Motion event construal by advanced L2 French-English and L2 FrenchGerman speakers. Language, Interaction and Acquisition (LIA) 3:2, 202-230.

Champaud, C., Bassano, D., Hickmann, M. (1993). Modalité épistémique et discours rapporté chez l'enfant français. In N. Dittmar \& A. Reich (Eds.), Modalité et acquisition des langues (pp. 185-209). Berlin: The Gruyter.

Cheng, P. W., Novick, L. R. (1991). Causes versus enabling conditions. Cognition 40, 83120.

Costa, A., Foucart, A., Arnon, I., Aparici, M., Apesteguia, J. (2014). "Piensa" twice: On the foreign language effect in decision making. Cognition 130 (2), 236-254.

Croft, W., Cruse, D. A. (2004). Cognitive Linguistics. Cambridge: Cambridge University Press.

Declerck, R. (2006). The Grammar of the English Tense System: A Comprehensive Analysis. Berlin: Mouton de Gruyter.

Dowty, D. (1991). Thematic proto-roles and argument selection. Language 67/3, 547-619.

Dray, K., Uphill, M. A. (2009). A survey of athletes counterfactual thinking: Precursors, prevalence, and consequences. Sport \& Exercise Psychology Review 5 (1), 16-26.

Ellis, N. C., Römer, U., O’Donnell, M. B. (2016). Usage-based Approaches to Language Acquisition and Processing: Cognitive and Corpus Investigations of Construction Grammar. Oxford: Wiley.

Gilabert, R., Barón, J., Levkina, M. (2011). Manipulating task complexity across task types and modes. In Robinson P. (Ed.), Second Language Task Complexity. Researching the Cognition Hypothesis of language learning and performance. Amsterdam: John Benjamins. 105-138. 
Harris, P. L., German, T., Mills, P. (1996). Children's use of counterfactual thinking in causal reasoning. Cognition 61, 233-259.

Hume, D. (1739/1992). Treatise of Human Nature. New York: Prometheus.

Hung, P. H. (2012). L'acquisition de l'expression de la spatialité en mandarin langue étrangère par des apprenants francophones. Ph. Dissertation under the supervision of Daniel Véronique. Aix-Marseille University. https://www.theses.fr/2012AIXM3125

Kahneman, D., Tversky, A. (1982). The simulation heuristic. In D. Kahneman, P. Slovic and A. Tversky, Judgment under uncertainty, (pp. 201-208). Cambridge: Cambridge University Press.

Keysar, B., Hayakawa, S., An, S. G. (2012). The foreign language effect: Thinking in a foreign tongue reduces decision biases. Psychological science 23, 661-668.

Lewis D. (1973/1976), Counterfactuals. Cambridge: Harvard University Press.

Mackie, J. L. (1974). Causation. Oxford: Oxford University Press.

Mandel, D. R. \& Lehman, D. R. (1996). Counterfactual thinking and ascriptions of cause and preventability. Journal of Personality and Social Psychology 71(3): 450-463. DOI: 10.1037/0022-3514.71.3.450

Miller, D. T., Gunasegaram, S. (1990). Temporal Order and the Perceived Mutability of Events: Implications for Blame Assignment. Journal of Personality and Social Psychology 59, No. 6, 1111-1118.

Piaget, J. (1963). La construction du réel chez l'enfant. Paris : Delchaux et Niestlé.

Real Academia Española: Banco de datos CORDE en línea. Corpus diacrónico del español. http://www.rae.es [Consulté le 24/11/2015].

Reilly, J. S. (1982). The Acquisition of Conditionals in English. Ph. Dissertation, Los Angeles: University of California.

Repiso, I. (2014). La production des scenarios contrefactuels par des apprenants adultes hispanophones : quelques effets d'étrangeté liés à l'emploi du conditionnel en français langue étrangère. Language, Interaction, Acquisition 5:2, 252-281.

Repiso, I. (2013). Parlons de l'irréel. L'expression de la contrefactualité en français, en espagnol et en italien et en français langue étrangère par des hispanophones et des italophones. Ph. Dissertation under the supervision of Daniel Véronique. Aix-Marseille University \& Universidad de Salamanca. http://www.theses.fr/2013AIXM3126 
Rey-Debove, J., Rey, A. (2004). Le Petit Robert. Paris : Le Robert.

Rittle-Johnson, B., Wagner Alibali, M. (1999). Conceptual and Procedural Knowledge of Mathematics: Does One Lead to the Other? Journal of Educational Psychology, Vol. 91, No. 1, 175-189.

Schalley, A. C. (2004). Cognitive Modeling and Verbal Semantics. A Representational Framework Based on Unified Modeling Language. Berlin: Mouton De Gruyter.

Slobin, D. (1996). From "Thought and Language" to "Thinking for Speaking". In J. J. Gumperz \& S. C. Levinson (eds.), Rethinking Linguistic Relativity (pp. 70-96). Cambridge: Cambridge University Press.

Summerville, A., Roese, N. J. (2008). Dare to compare: Fact-based versus simulation-based comparison in daily life. Journal of Experimental Social Psychology 44, 664-671.

Talmy, L. (2000). Toward a Cognitive Semantics: Typology and Process in Concept Structuring. Cambridge, MA: MIT Press.

Tournadre, N., LaPolla, R. (2014). Towards a new approach to evidentiality: Issues and directions for research. Linguistics of the Tibeto-Burman Area 37(2). Amsterdam: John Benjamins.

Van Valin, R. D., LaPolla, R. J. (1997). Syntax: Structure, Meaning and Function. Cambridge: Cambridge University Press.

Wells, G. L., Gavanski, I. (1989). Mental simulation of causality. Journal of personality and social psychology 56 (2), 161-169.

\section{Annexes}

A. Summary of French-speaking participants

\begin{tabular}{|c|c|c|c|c|}
\hline Subject & L1 & Sex & Age & $\begin{array}{c}\text { Geographical } \\
\text { provenance }\end{array}$ \\
\hline 1 & French & F & 21 & Southeast France \\
\hline 2 & French & F & 22 & Southeast France \\
\hline 3 & French & F & 21 & Southeast France \\
\hline 4 & French & F & 56 & Paris \\
\hline 5 & French & F & 20 & Southeast France \\
\hline 6 & French & F & 25 & Southeast France \\
\hline 7 & French & F & 20 & Southeast France \\
\hline 8 & French & F & 55 & Southeast France \\
\hline 9 & French & M & 26 & Northern France \\
\hline 10 & French & F & 26 & Southeast France \\
\hline 11 & French & F & 52 & Southeast France \\
\hline 12 & French & M & 28 & Paris \\
\hline 13 & French & M & 39 & Southeast France \\
\hline
\end{tabular}




\begin{tabular}{|c|c|c|c|c|}
\hline 14 & French & F & 29 & Southeast France \\
\hline 15 & French & M & 30 & Eastern France \\
\hline 16 & French & M & 17 & Southeast France \\
\hline 17 & French & M & 22 & Southeast France \\
\hline 18 & French & F & 21 & Quebec \\
\hline 19 & French & M & 33 & Paris \\
\hline 20 & French & M & 33 & Paris \\
\hline 21 & French & M & 29 & Eastern France \\
\hline 22 & French & F & 28 & Southeast France \\
\hline 23 & French & F & 23 & Southeast France \\
\hline 24 & French & F & 30 & Northern France \\
\hline 25 & French & F & 27 & Southeast France \\
\hline 26 & French & F & 25 & Southeast France \\
\hline 27 & French & M & 25 & Southeast France \\
\hline 28 & French & F & 23 & Southeast France \\
\hline 29 & French & F & 23 & Southeast France \\
\hline 30 & French & F & 21 & Southeast France \\
\hline
\end{tabular}

B. Summary of Spanish-speaking participants

\begin{tabular}{|c|c|c|c|c|c|c|c|}
\hline Subject & L1 & Sex & Age & $\begin{array}{l}\text { Geographical } \\
\text { provenance }\end{array}$ & $\begin{array}{c}\text { FFL } \\
\text { studies }\end{array}$ & Immersion & $\begin{array}{c}\text { Random } \\
\text { order }\end{array}$ \\
\hline 1 & Spanish & $\mathrm{M}$ & 26 & Colombia & 7 years & 1 an & L1-FLE \\
\hline 2 & Spanish & M & 24 & Southern Spain & 4 years & 3 months & L1-FLE \\
\hline 3 & Spanish & $\mathrm{M}$ & 35 & Colombia & 9 years & 9 years & FLE-L1 \\
\hline 4 & Spanish & $\mathrm{F}$ & 33 & Southern Spain & 7 years & 4 years & L1-FLE \\
\hline 5 & Spanish & $\mathrm{F}$ & 33 & Mexico & 9 years & 6 years & L1-FLE \\
\hline 6 & Spanish & $\mathrm{F}$ & 27 & Colombia & 3 years & 2 years & L1-FLE \\
\hline 7 & Spanish & $\mathrm{F}$ & 28 & Northern Spain & 20 years & 1 month & FLE-L1 \\
\hline 8 & Spanish & $\mathrm{F}$ & 23 & Southern Spain & 8 years & 1 year & L1-FLE \\
\hline 9 & Spanish & $\mathrm{F}$ & 29 & Colombia & 4 years & 1 year & FLE-L1 \\
\hline 10 & Spanish & $\mathrm{F}$ & 30 & Colombia & 15 years & 1 year & FLE-L1 \\
\hline 11 & Spanish & $\mathrm{M}$ & 22 & Northern Spain & 3 years & 3 month & FLE-L1 \\
\hline 12 & Spanish & $\mathrm{F}$ & 25 & Madrid & 2 years & 5 month & L1-FLE \\
\hline 13 & Spanish & $\mathrm{M}$ & 23 & Eastern Spain & 2 years & 3 month & FLE-L1 \\
\hline 14 & Spanish & $\mathrm{F}$ & 28 & Northern Spain & 6 months & 2 years & L1-FLE \\
\hline 15 & Spanish & $\mathrm{F}$ & 32 & Chile & 0 & 1 year & FLE-L1 \\
\hline 16 & Spanish & $\mathrm{F}$ & 21 & Madrid & 15 years & 17 years & FLE-L1 \\
\hline 17 & Spanish & $\mathrm{F}$ & 44 & Northern Spain & 11 years & 24 years & L1-FLE \\
\hline 18 & Spanish & $\mathrm{F}$ & 44 & Northern Spain & 12 years & 24 years & FLE-L1 \\
\hline 19 & Spanish & $\mathrm{M}$ & 33 & Eastern Spain & 5 months & 8 month & FLE-L1 \\
\hline 20 & Spanish & $\mathrm{M}$ & 38 & Mexico & 2.5 years & 4 years & L1-FLE \\
\hline 21 & Spanish & $\mathrm{F}$ & 27 & Madrid & 5 years & 5 years & FLE-L1 \\
\hline 22 & Spanish & $\mathrm{M}$ & 24 & Northern Spain & 2 years & 15 years & L1-FLE \\
\hline 23 & Spanish & $\mathrm{F}$ & 37 & Northern Spain & 5 years & 19 month & FLE-L1 \\
\hline 24 & Spanish & $\mathrm{M}$ & 36 & Mexico & 1 year & 9 years & L1-FLE \\
\hline 25 & Spanish & $\mathrm{M}$ & 29 & Mexico & 2 years & 4.5 years & FLE-L1 \\
\hline 26 & Spanish & $\mathrm{M}$ & 37 & Southern Spain & 4 years & 6 month & L1-FLE \\
\hline 27 & Spanish & $\mathrm{M}$ & 34 & Mexico & 1 year & 10 years & FLE-L1 \\
\hline 28 & Spanish & $\mathrm{M}$ & 38 & Colombia & 1 year & 6 years & L1-FLE \\
\hline 29 & Spanish & $\mathrm{M}$ & 43 & Chile & 3 years & 9 years & FLE-L1 \\
\hline 30 & Spanish & $\mathrm{M}$ & 33 & Peru & 12 years & 9 years & L1-FLE \\
\hline
\end{tabular}

C. Materials in Spanish 


\section{$\underline{\text { Stimulus }}$}

Karen era asistente a la edición en una pequeña empresa de publicidad. Padecía una rara enfermedad hereditaria llamada hemotrisoma de Karpinson, caracterizada por la falta de una enzima que normalmente divide algunas proteínas en el aparato digestivo. Por ello las bebidas fermentadas como el vino o el licor podían causarle graves reacciones alérgicas.

Karen había sido ascendida de manera que su superior, el señor Carlson, la llevó a un caro restaurante francés para celebrarlo. El señor Carlson había comido en dicho restaurante varias veces, así que pidió por los dos. Mientras miraba el menú se preguntó qué pedir para Karen. Primero pensó en pedir unas vieiras pero en el último momento se decidió por los mejillones a la marinera. Aunque el señor Carlson no lo sabía, los mejillones a la marinera llevaban una salsa a base de vino mientras las vieiras, no.

Karen disfrutó de la comida pero empezó a sentirse mal poco después. En cuestión de minutos sufrió convulsiones y fue socorrida en una ambulancia. Karen murió de camino al hospital.

\section{Instruction}

Propón tres modificaciones que hubieran evitado la muerte de Karen y explica por qué habrían evitado su muerte.

D. Original materials in English

\section{$\underline{\text { Stimulus }}$}

Karen was an assistant editor for a small publishing firm. She had a rare hereditary disease called Karpinson's hemotrysoma, characterized by the lack of an enzyme that normally breaks down certain proteins in the digestive system. Because of this, fermented drinks such as wine and liqueurs can cause a severe allergic reaction in someone with the disease.

Karen had just received a promotion so her boss, Mr. Carlson, took her to an expensive French restaurant to celebrate. Mr. Carlson had been to this restaurant several times, so he ordered for both of them. As he looked over the menu, Mr. Carlson considered what to order for Karen. He first thought about ordering the Coquilles Saint-Jacques, but at the last moment decided on the Moules Mariniere instead. Although Mr. Carlson did not know this, the Moules Mariniere was made in a wine sauce whereas the Coquilles Saint-Jacques did not contain any wine.

Karen enjoyed her meal greatly, but began to feel ill shortly after finishing. Within minutes, she went into convulsions and was rushed away in an ambulance. She died on the way to the hospital.

Instruction

Imagine three modifications that could have been different in the story to avoid Karen's death. 